\title{
Morphological study of Honeybees (Apis mellifera) from Libya*
}

\author{
Taher SHAIBI $^{1}$, Stefan FuCHS ${ }^{2}$, Robin F.A. MORITZ ${ }^{1}$ \\ ${ }^{1}$ Institut für Biologie, Martin-Luther-Universität Halle-Wittenberg Hoher Weg 4, 06099 Halle/Saale, Germany \\ ${ }^{2}$ Institut für Bienenkunde Fachbereich Biologie der J. W. Goethe-Universität Frankfurt am Main \\ Karl-von-Frisch-Weg 2, 61440 Oberursel, Germany
}

Received 21 November 2007 - Revised 6 September 2008 - Accepted 13 October 2008

\begin{abstract}
We show, with classical morphometrical analyses, that Libyan honeybees sampled at coastal and desert locations are distinctly different from both the adjacent $A$. m. intermissa bee populations of Tunisia and Algeria and those of A. m. lamarckii of Egypt. The morphotype was most closely related to A. $m$. sahariensis and, based on wing venation angles, showed affinities to A. $m$. jemenitica, indicating that the sampled populations might be derived from a formerly extended Saharan honeybee population during the Holocene pluvial. Scattered morphometric similarities to the European bee A. m. ligustica suggest that importation of honeybees from Italy may have had only minor impact on endemic Libyan honeybee populations. Conservation measures might be particularly appropriate for remote oasis populations, which might be true relic population from the Holocene.
\end{abstract}

\section{Apis mellifera / morphometry / Libya / sahariensis / conservation}

\section{INTRODUCTION}

Apis mellifera L. is widespread in Africa, Europe and parts of Asia with a wide diversity of subspecies that can be classified with morphometric tools (Ruttner et al., 1978). Ruttner et al. (1978) suggested that Apis mellifera split into three different biogeographical branches; (A) one of South and Central Africa, (M) one of Western Europe and North Africa, and (C) one of the North Mediterranean. Subsequently, Ruttner (1988) added the branch (O), which included the near and Middle Eastern subspecies. All these branches (A, M, C and $\mathrm{O}$ ) are found around the Mediterranean where they are represented by 16 identified subspecies. The general pattern of subspecies distribution was subsequently in principle supported by various studies using molecular tools (Garnery et al., 1993; Franck et al., 2000,

Corresponding author: T. Shaibi, taher.shaibi@zoologie.uni-halle.de * Manuscript editor: Walter S. Sheppard
2001; Whitfield et al., 2006). Nevertheless, the subspecies of northwestern Africa and some populations of $A$. $m$. iberica were assigned to Branch A instead of M, whereas A. m. lamarckii remained ambiguous, either A or O.

Since Libyan bees are geographically located between A. m. lamarckii of Egypt in the east and the other North African subspecies A. m. intermissa and sahariensis in the west, Libya provides a missing link in this west-east transition. About 125000 managed colonies were estimated to exist in Libya in 1999 (Al Mahjoob et al., unpublished report). Although apiculture has an old tradition in the country, little attention has been paid to study the honeybees of Libya apart from some morphometric investigations (El Banby, unpubl. data), studies on honey quality (Mohaned et al., 1981), pest control (Kosheim, 1998) and beekeeping activity (Hussein, 2000a, b). Today, there are three main regions with modern beekeeping along the Mediterranean coast line with only scattered apicultural activities in the rest of the country. 


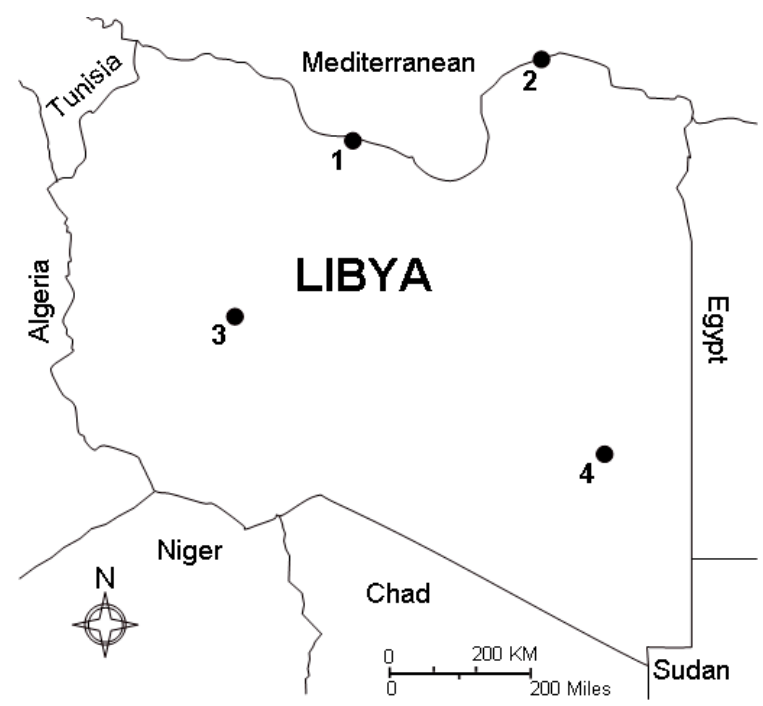

Figure 1. Map of Libya showing the locations of samples: (1) Surt $\left(31^{\circ} 12^{\prime} 19.01^{\prime \prime} \mathrm{N}, 16^{\circ} 35^{\prime} 18.13^{\prime \prime} \mathrm{E}\right)$; (2) Baida $\left(32^{\circ} 44^{\prime} 58.27^{\prime \prime} \mathrm{N}, 21^{\circ} 37^{\prime} 14.02^{\prime \prime} \mathrm{E}\right)$; (3) Brak $\left(27^{\circ} 32^{\prime} 15.72^{\prime \prime} \mathrm{N}, 1^{\circ} 14^{\prime} 43.44^{\prime \prime} \mathrm{E}\right)$; (4) Kufra $\left(24^{\circ} 11^{\prime} 07.08^{\prime \prime} \mathrm{N}, 23^{\circ} 18^{\prime} 54.00^{\prime \prime} \mathrm{E}\right)$.

Molecular evidence suggests that all North African bees firmly belong to the African branch, but $A$. m. lamarckii showing close affinities to the molecular Oriental branch. The intermediate position of $A$. $m$. lamarckii between African and Oriental bees is also morphometrically well supported. On the western side $A$. $m$. sahariensis clearly belongs to the morphometric A branch, while A. m. intermissa is set apart resembling bees of the European M branch (Ruttner, 1988). Reliable data to assign Libyan honeybees to either branch are lacking, although there are some anecdotal reports that the bees of Libya may be a distinct ecotype (El Banby, 1977). The morphometric analysis of the honeybees of Libya in this study therefore provides an opportunity to understand the characteristics, biogeography and spread of honeybees around the Mediterranean.

\section{MATERIALS AND METHODS}

\subsection{Sampling and morphometric analysis}

Samples of adult worker bees were collected from 11 colonies in 2005 at four modern apiaries in Libya (Fig. 1): Kufra (3), Baida (3), Brak (3) and Surt (2) and preserved in $90 \%$ ethanol. The distant sample locations were chosen to represent different parts of the country with very different ecological conditions.

Ten worker bees of each sample were morphometrically analyzed by using 37 characters as described in Ruttner et al. (1978). These comprised 16 measurements of length, 7 of coloration, 3 of pilosity and 11 wing angles. Pigmentation characters and hair length were microscopically analyzed. All other characters were digitally measured with a CCD camera combined with an on-screen measuring system (Bee2, Meixner, 1994).

\subsection{Statistical analysis}

The colony means, standard deviations, and standard errors of each character of a worker sample was computed and used for the further analysis. The data were compared with reference samples of five other African subspecies adjacent or within the North African desert belt from the morphometric data base of the Institut für Bienenkunde, Oberursel including A. m. intermissa (7 colonies), A. m. sahariensis (6 colonies) and A. m. lamarckii, (8 colonies), A. m. jemenitica (49 colonies) and A. $m$. litorea ( 9 colonies). Three different approaches were taken to assess the similarity among the bees. 
The data were first submitted to a principal component analysis (PCA) to assess general similarities. Then data were submitted to stepwise discriminant analysis (DA) with the Libyan samples considered either as separate groups or as members of other groups. Lastly, morphometric distances were calculated on Z-normalized measurements and distance data were submitted to cluster analysis (CA). In a second analysis, reference samples of the European subspecies A. m. ligustica (12) were included into DA based only on the 11 wing angles to test for possible introgression through commercial imports of queens and colonies from Italy. All statistical analyses were performed using the SPSS 15.0 statistical software (SPSS, 2006).

\section{RESULTS}

The Libyan bee samples significantly differed from all reference groups by at least some of the measurements. The bees were smaller or close to A. m. intermissa, A. m. sahariensis and A. m. ligustica but distinctly bigger than A. m. lamarckii, A. m. jemenitica or A. $m$. litorea. Total leg size, forewing length and forewing width (Tab. I) of the Libyan bees were larger than in $A$. m. jemenitica and A. $m$. litorea, the latter also being smaller in tergite size (sum of tergit 3 and 4). The samples did not differ in slenderness (the quotient of length by width of tergite 6 ) from the same first three subspecies as above, but were significantly more slender compared to the other three subspecies. The Libyan samples were particularly set apart by broad hindleg metatarsi, expressed by a significantly higher metatarsal index compared to all other groups. They were further set apart by exceeding all other groups in the length of the wax mirror, while the width of the wax mirror was indiscriminate from $A$. $m$. intermissa, A. m. sahariensis and A. m. ligustica. This resulted in a conspicuously and significantly higher wax mirror index compared to all other groups. Concerning pigmentation, the Libyan samples were light colored and did not differ much from the other light colored subspecies except from A. m. intermissa, which is distinctly darker. Cubital veins were longer than in all other groups except $A$. m. ligustica for cubital vein 1 , resulting in a significantly lower cubital index than this subspecies. They showed significantly lower values for wing angle D7 and G18 than all other groups except $A$. $m$. ligustica, from which they differed by having significantly smaller wing venation angles B4 and N23, and a larger wing venation angle L13.

A PCA analysis on colony means of the 37 characters of the 11 colonies at the four Libyan locations together with colony means of the African reference samples captured 58\% of the variance on the first three PCA axes. The first axis was mainly loaded with length measures with the positive values indicating larger size values. The second axis was predominantly loaded with colors with high values indicating lighter coloration, and the third one by the wing angles a4, b4, d7 and e9. On PCA sample score plots, one cluster contained A. m. jemenitica, A. m. litorea and A.m. lamarckii, while A. m. intermissa constituted a separate cluster. Libyan samples formed a separate cluster together with A. m. sahariensis, with the samples from Kufra set at the extreme end of this cluster into the direction of extreme values of size and lightness of coloration (Fig. 2).

A similar pattern emerged in the DA where all Libyan bees were reallocated to the Libya group with a post-hoc probability of $P>$ 0.9995. In a plot of the first two discriminant functions, all Libyan samples formed a separate cluster clearly apart from all other subspecies, showing the uniqueness of their status (Fig. 3). Above this, all four Libyan locality groups were reallocated with post-hoc probabilities of $P>0.9995$ indicating strong local variation. The Euclidian distance of all local group centroids was smallest to the centroid of A. m. sahariensis.

If the samples of Libya were force-allocated into the reference groups all were allocated to A. $m$. sahariensis with very high post-hoc probabilities ( 9 colonies with $P>0.9995,2$ from Surt with $P>0.995$ ).

A CA based on Euclidian morphological distances of z-normalized character means for the localities and the means of the reference groups further confirmed these relations. The distance relations were submitted to a CA using average linkage (Fig. 4), clearly demonstrating the similarities between the Libyan localities, with Kufra distinctly more apart. 


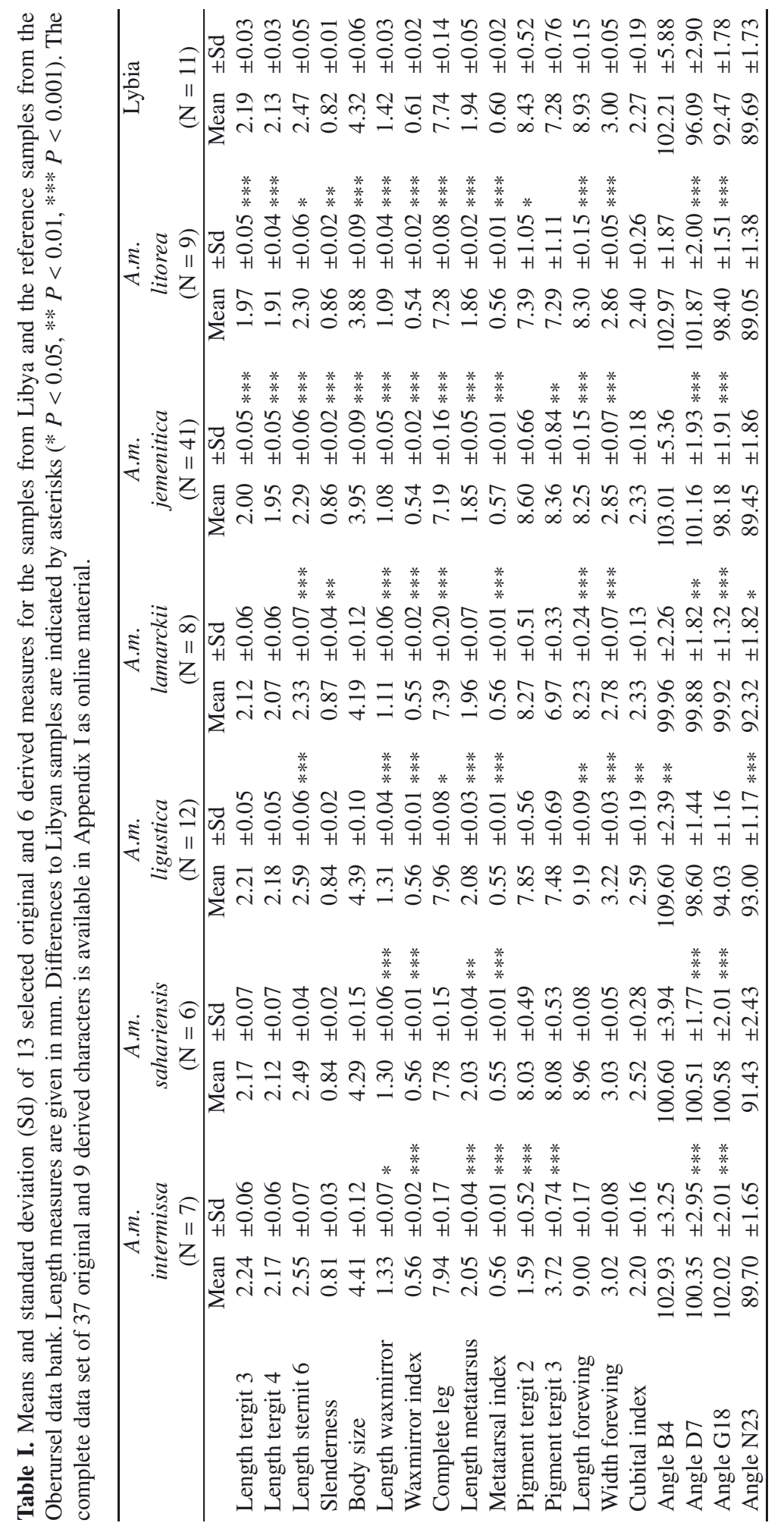




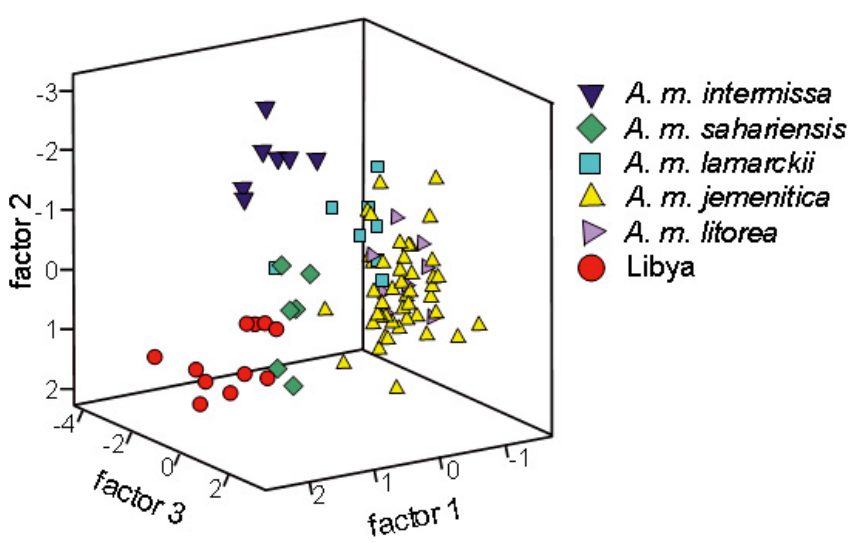

Figure 2. Principal component scores of bee samples from Libya and of the African reference groups. High factor one values indicate larger size measures, high factor two values lighter coloration. Factor three correlates with predominantly with wing venation angles.

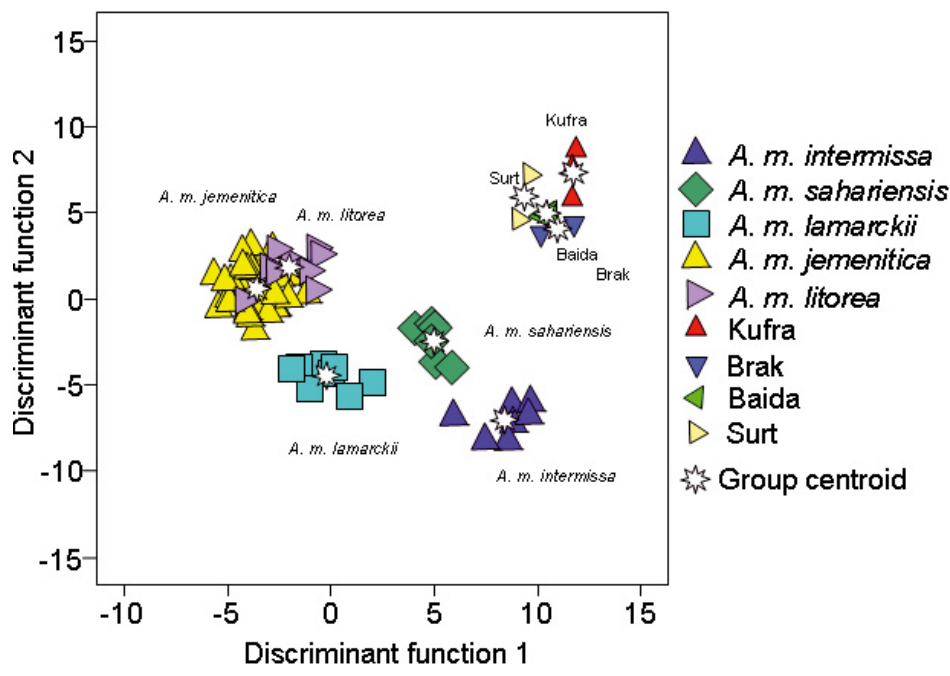

Figure 3. Discriminant function sample scores of bee samples from four locations from Libya (small symbols) and of African reference groups (big symbols), together with their group centroids.

The placement of $A$. $m$. sahariensis within the same cluster underlines the close morphometric similarity to this subspecies. In contrast, $A$. $m$. intermissa is placed in a separate position, while A. m. jemenitica, A. $m$. litorea and A. $m$. lamarckii form an even more distant, separate cluster.

To evaluate the possible influence of bee importation, A. m. ligustica was included into the analysis. In a forced DA, 9 of the Libyan samples were allocated to A. $m$. sahariensis with high post-hoc probabilities $(P>0.9995)$.
One sample from Surt was intermediate between A. $m$. sahariensis and A. m. ligustica, while one sample from Brak was allocated with high post-hoc probability to $A$. $m$. ligustica. Because of difficulties arising from similarities of size and coloration between $A$. $m$. ligustica and A. m. sahariensis, we repeated all analyses using the wing venation pattern only (11 wing angles) and excluded $A$. $m$. litorea to reduce the number of groups in relation to the number of characters. In this analysis, eight of the Libyan samples were reallocated into 


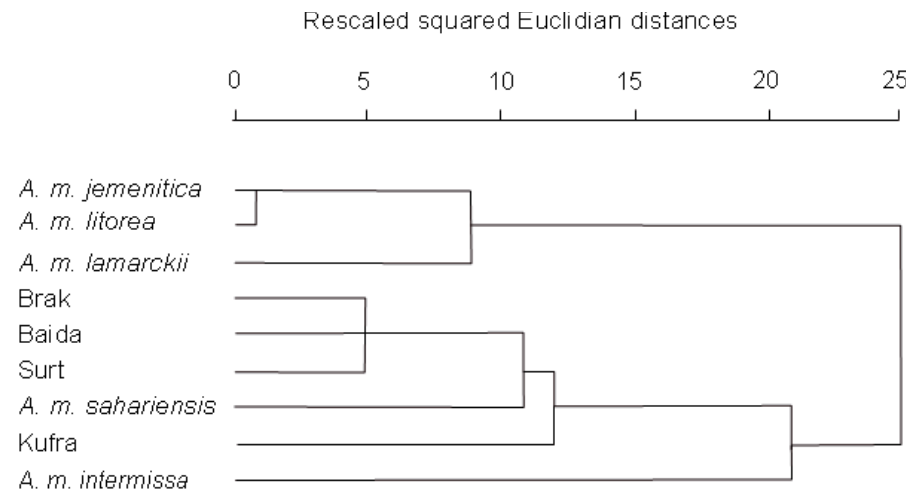

Figure 4. Dendrogram of a cluster analysis based on squared Euclidian distances of the z-normalized character means of the colony samples of the four Libyan locations and of the African references samples.

the Libya group with post-hoc probabilities of $P>0.99$, and two with lower probabilities with a second choice of $A$. m. ligustica and A. $m$. jemenitica. The remaining sample from Brak was allocated to A. m. lamarckii with a low post-hoc probability $(P=0.77)$ and a second choice for $A$. $m$. sahariensis $(P=0.20)$. In a forced allocation, the majority of eight samples was allocated to A. m. jemenitica, while two (one from Brak and one from Surt) were allocated to A. m. lamarckii and one from Brak to A. m. ligustica.

\section{DISCUSSION}

Though the number of sampling locations is low, the sampled of colonies displayed homogenous morphotypes, with significant deviations to other subspecies in the region forming concise morphoclusters in all multivariate analyses. El Banby (1977) studied the honeybees of Al Jabel Akhdar, in northeast Libya, and concluded that these bees belonged neither to A. m. intermissa nor to A. m. lamarckii found in Egypt, but represented a different type more similar to A. m. lamarckii than to intermissa. Although no further details or data were given in this first morphological study, we here clearly confirm El Banby's suggestion of a distinct honeybee ecotype in Libya. In all our analyses, the Libyan honeybees were clearly set apart from the adjacent subspecies as a separate and distinct cluster. We agree with El Banby that the Libyan honeybees are very different from A. m. intermissa, although this subspecies is widespread in North Africa west of Libya (Barour, 2005; Lebdi-Grissa, 1991a, b; Hepburn and Radloff, 1996). However, we found no consistent evidence that the morphometric position of Libyan honeybees is significantly closer to $A$. m. lamarckii than to $A$. $m$. intermissa. Thus, in spite of the geographic proximity of Baida and Kufra to Egypt, Libyan bees apparently have only little in common with Egyptian A. m. lamarckii. Surprisingly, the samples from Libya rather showed similarities to the geographically much more distant north-western African bee A. m. sahariensis, a yellow, gentle bee originally described from the oases of Western Algeria and Southern Morocco (Baldensperger, 1924, from Ruttner, 1988). Considering wing angles alone, which are genetically more conservative characters in comparison to size and coloration, (Diniz-Filho et al., 1999), Libyan bees rather exhibit similarities to A. $m$. jemenitica, the sub-Saharan honeybee extending along the Sahelian dry-tropical zones from west to east throughout the continent.

The closer relation of Libyan bees to $A$. $m$. sahariensis or the sub-Saharan A. m. jemenitica rather than to $A$. $m$. intermissa might not be entirely surprising. Franck et al. (2001) suggested that the distinctness of the North African subspecies A. m. intermissa from the sub-Saharan African subspecies may reflect a separation during the dry period in the late Pleistocene around 15000 years B.P. Ruttner 
(1988) suggested that A. m. sahariensis might be a relic population from the Holocene pluvial ( $~ 8000$ B.P), when the Sahara consisted of mainly grassland with only narrow desert strips. Our results indicate that Libyan bees, similar to A. m. sahariensis, might be derived from a large extended bee population which had re-colonized extensive parts of the Sahara some thousands years ago, living under similar environmental conditions as A. m. jemenitica or A. m. sahariensis today.

A further noteworthy result of our study is the morphometric affinity of Libyan bees to the European subspecies A. m. ligustica which one might interpret as an indication of introgression at first sight. However, in spite of this similarity, this cannot be unambiguously attributed to an effect of bee importation to Libya, because A. m. sahariensis and A. $m$. ligustica reveal the same resemblance. Obviously the similarities are mainly based on measures of size and coloration, and a clear differentiation of $A$. $m$. ligustica from the African bee groups can be better obtained by using the wing venation angles alone. However, even on this more robust data set we cannot exclude that the importation of commercial bees has not influenced the morphometric characters of Libyan bees. About 50000 units (colonies, package bees and queens) of $A$. $m$. ligustica and some 3600 colonies of A. m. carnica, were imported to Libya between the 1970's and the 1990's (Al Mahjoob et al., unpublished report). Moreover, a commercial hybrid line between A. m. carnica and A. m. lamarckii called "Queens Wadi" was marketed in Libya (Simonthomas and Simonthomas, 1980) and both might have had impact on local populations. The similarities to A. m. ligustica were most strongly expressed in the bees from Brak, where one sample was consistently allocated to the A. m. ligustica cluster in the DA. Similarly, one sample from Surt also showed strong affinities to A. m. ligustica. Migratory beekeeping operations occur at both sites. In contrast, the samples from the remote oasis of Kufra were distinctly closer to A. m. sahariensis than to A. m. ligustica, supporting that of the investigated locations Kufra might hold a well-conserved population of the autochtonous Libyan honeybee type.
The potential introgression of European races on the honeybees of Libya contrasts to reports from Tunisia, where Lebdi-Grissa et al. (1991a, b) compared European with Tunisian honeybees. They found no significant effect on Tunisian bees, in spite of repeated intensive efforts in all the Maghreb to import $A$. m. ligustica, A.m. macedonica, A.m. mellifera, A.m. carnica and A.m. caucasica (Hicheri and Bouderbala, 1969; Second, 1974; Lebdigrissa et al., 1991a). Although Hepburn and Radloff (1998) refer to failures of honeybee imports to Libya, our findings suggest that more in depth studies are needed including analysis of mitochondrial and genomic DNA to confirm any impact of European A. mellifera on the Libyan bee population (Moritz et al., 2005, $2007,2008)$. If the indications from our biometrical study prove to be the result of actual introgression of imported honeybee stock, this would make evident the need for conservation measures in Libya from a biodiversity perspective.

\section{ACKNOWLEDGEMENTS}

We thank Beate Springer for her contribution to the lab work. This work is financed by the Ministry of Highly Education of Libya (TS) and the EU Commission DG Research (Strategic Research Project FOOD-CT-2006-022568 BEE SHOP) (RFAM).

Étude morphologique des abeilles (Apis mellifera) de Libye.

Apis mellifera sahariensis / Apis mellifera jemenitica / sous-espèce / morphométrie / Libye / biodiversité / conservation

Zusammenfassung - Morphologische Untersuchung zu Honigbienen (Apis mellifera) aus Libyen. In dieser Arbeit werden Honigbienen Libyens mit den anderen Bienenrassen des mediterranen Raums und der Sahara verglichen. Je 10 Arbeiterinnen wurden von 11 Völkern an vier verschiedenen Standorten (Kufra (3), Baida (3), Brak (3), Surt (2); Abb. 1) in Libyen mit einem Standardset von 37 Merkmalen morphometrisch analysiert (Tab. I). Diese Daten wurden mit denen der biometrischen Datenbank des Instituts für Bienenkunde, Oberursel verglichen. Alle Daten 
wurden einer Faktorenanalyse, einer Diskriminanzanalyse und einer Clusteranalyse unterzogen. Die Hauptkomponenten- Analyse zeigte, dass die libyschen Proben einen separaten Kluster bilden, der eine höhere Ähnlichkeit zu A. m. saharensis als zu den anderen afrikanischen Bienenrassen zeigt (Abb. 2). Ein ähnliches Ergebnis wurde auch in der Diskriminanzanlyse erzielt (Abb. 3) in der die meisten libyschen Proben korrekt zur eigenen Gruppe zugeordnet wurden. Auch die auf den euklidischen Distanzen zwischen den Mittelwerten der Merkmale in den Gruppen beruhende Klusteranalyse zeigte, dass die libyschen Proben nahe zusammen liegen und betonte die Nähe zu A. m. sahariensis, die innerhalb des gleichen Klusters angeordnet wurde. Insgesamt zeigten die Proben von Kufra die höchste Ähnlichkeit zu A. m. sahariensis, während die beiden nordafrikansichen Rassen A. m. intermissa in Westen und A. m. lamarckii in Osten deutlich weniger Gemeinsamkeiten mit den libyschen Honigbienen aufwiesen. Unserer Analyse belegt, dass die libyschen Honigbienen einen distinkten Ökotyp darstellt, mit Anklängen an A. m. sahariensis und, besonders in den Flügelwinkeln, auch an A. $m$. jemenitica darstellt. Zusammen mit A. $m$. sahariensis stellt sie möglicherweise eine Reliktpopulation aus dem Holozän dar. Unsere Analyse zeigte weiterhin Anzeichen auf eine mögliche Introgression importierter Europäischer Bienenrassen auf die endemische Population in Libyen, die Schutzmaßnahmen zur Erhaltung der Biodiversität dieser spezifischen Wüstenbiene angezeigt sein lassen könnten.

\section{Apis mellifera / Morphometrie / Libyen / sahari- ensis / Erhaltung der Biodiversitât}

\section{REFERENCES}

Barour C., Tahar A., Radloff S.E., Hepburn H.R. (2005) Multivariate analysis of honeybees, Apis mellifera Linnaeus (Hymenoptera: Apidae) of the northeastern and southern regions of Algeria, Afr. Entomol. 13, 17-23.

Diniz-Filho J.A., Fuchs S., Arias M.C. (1999) Phylogeographic correlations of morphological evolution in honey bees (Apis mellifera L.), Heredity 83, 671-680.

El Banby M.A. (1977) Biometrical studies on the local honeybee of the Libyan Arab People's Socialist Jamachiriya, Proc. Int. Beekeep. Congr. 26, 269.

Franck P., Garnery L., Solignac M., Solignac M., Cornuet J.M. (2000) Molecular confirmation of a fourth lineage in honeybees from the Near East, Apidologie 31, 167-180.

Franck P., Garnery L., Loiseau A., Oldroyd B.P., Hepburn H.R., Solignac M., Cornuet J.M. (2001) Genetic diversity of the honeybee in Africa: microsatellite and mitochondrial data, Heredity 86, 420-430.
Garnery L., Solignac M., Celebrano G., Cornuet J.M. (1993) A simple test using restricted PCRamplified mitochondrial DNA to study the genetic structure of Apis mellifera L., Experientia 49, 1016-1021.

Hicheri K., Bouderbala M. (1969) Tunisian apiculture, 20 Int. Beekeep. Congr., Apimondia, Bucharest, Romania, pp. 440-443.

Hepburn H.R., Radloff S.E. (1996) Morphometric and pheromonal analyses of Apis mellifera L. along a transect from the Sahara to the Pyrenees, Apidologie 27, 35-45.

Hepburn H.R., Radloff S.E. (1998) Honeybees of Africa, Springer-Verlag, Berlin.

Hussein M.H. (2000a) A review of beekeeping in Arab countries, Bee World 81, 56-71.

Hussein M.H. (2000b) Beekeeping in Africa: I. North, East, North-East and West African countries, Apiacta 1, 32-48.

Kosheim E. (1998) Investigation of the performance of some acarisides on parasitic mite (Varroa jacobsoni) of honeybees, 2nd Inter. Arab Apic. Conf., Amman, 65-67.

Lebdi-Grissa K., M'Sadda K., Cornuet J.M., Fresnaye J. (1991a) The influence of European honeybees introduced in Tunisia on the Tunisian breed Apis mellifera intermissa, Landbouwtijd-Rev. Agr. 44, 631-636.

Lebdi-Grissa K., M'Sadda K., Cornuet J.M., Fresnaye J. (1991b) Phylogenetic relationships between the Tunisian honeybee A. m. intermissa and neighboring African and west Mediterranean honeybee breeds, Landbouwtijd-Rev. Agr. 44, 1231-1238.

Meixner M.D. (1994) Analyse polymorpher Subspezies von A. mellifera L.: Morphometrische und molekulare Untersucheungen an den europäischen Rassen Apis mellifera carnica und ligustica und den afrikanischen Rassen A. m. monticula und scutellata, $\mathrm{PhD}$ Thesis, Fachbereich Biologie der J. W.- Goethe-Universität, Frankfurt am Main.

Mohaned M.A., Ahmed A.A., Mazid M.M. (1981) Studies on Libyan honeys, J. Food Qual. 4, 185201.

Moritz R.F.A., Härtel S., Neumann P. (2005) Global invasions of the western honey bee (Apis mellifera) and the consequences for biodiversity, Ecoscience 12, 289-301.

Moritz R.F.A., Kraus F.B., Kryger P., Crewe R.M. (2007) The size of wild honeybee populations (Apis mellifera) and its implications for the conservation of honeybees, J. Insect Conserv. 11, 391-397.

Moritz R.F.A., Dietemann V., Crewe R.M. (2008) Determining colony densities in wild honeybee populations (Apis mellifera) with linked microsatellite DNA markers, J. Insect Conserv. 12, 455-459. 
Ruttner F. (1988) Biogeography and taxonomy of honey bees, Springer-Verlag, Berlin.

Ruttner F., Tassencourt L., Louveaux J. (1978) Biometrical statistical analysis of the geographic variability of Apis mellifera L., Apidologie 9, 363381.

Second G. (1974) L'apiculture dans les pays d'Afrique du nord, Bull. Tech. Apic. 1, 7-28.

Simonthomas R.T., Simonthomas A.M.J. (1980) Philanthus triangulum and its recent eruption as a predator of honeybees in an Egyptian oasis, Bee World 61, 97-107.

SPSS (2006) SPSS for Windows, release 15, SPSS Inc., Chicago.

Whitfield C.W., Behura S.K., Berlocher S.H., Clark A.G., Johnston J.S., Sheppard W.S., Smith D.R., Suarez A.V., Weaver D., Tsutsui N.D. (2006) Thrice out of Africa: Ancient and recent expansions of the honey bee, Apis mellifera, Science 314, 642-645. 